\title{
A case of infantile systemic lupus erythematosus with severe lupus nephritis and EBV infection
}

\author{
Natsuko Kishi $\cdot$ Kenichi Suga $\cdot$ Sato Matsuura $\cdot$ Yukiko Kinoshita \\ Maki Urushihara $\cdot$ Shuji Kondo $\cdot$ Etsuko Kitano $\cdot$ Michiyo Hatanaka $\cdot$ \\ Hajime Kitamura $\cdot$ Tetsuya Sato $\cdot$ Akihiko Maeda $\cdot$ Shoji Kagami
}

Received: 23 August 2012 / Accepted: 7 January 2013/Published online: 14 February 2013

(C) Japanese Society of Nephrology 2013

\begin{abstract}
Infantile systemic lupus erythematosus (iSLE) is extremely rare. Patients with iSLE usually become severely unwell and have poor prognosis. Epstein-Barr virus (EBV) infection has been implicated in the development of SLE in both adults and children. Recently, we experienced a case of iSLE with severe lupus nephritis (LN) and EBV infection. A 14-month-old Japanese boy was diagnosed with iSLE according to the American Rheumatism Association criteria. Renal biopsy showed LN classified as International Society of Nephrology/Renal Pathology Society class IV-G (A), and liver biopsy showed lupus hepatitis. Steroid pulse treatment resulted in improvement of the levels of serological markers of SLE such as
\end{abstract}

N. Kishi $\cdot$ K. Suga $\cdot$ S. Matsuura $\cdot$ Y. Kinoshita

M. Urushihara $\cdot$ S. Kondo $\cdot$ S. Kagami

Department of Pediatrics, Institution of Health Biosciences,

The University of Tokushima Graduate School, Tokushima, Japan

\section{K. Suga $(\bowtie)$}

Department of Pediatrics, Tokushima Prefectural Central

Hospital, 10-3 Kuramotocho-1 chome,

Tokushima 770-8539, Japan

e-mail: ksuga@tph.gr.jp

E. Kitano $\cdot$ M. Hatanaka

Department of Medical Technology, Kobe Tokiwa University,

Kobe, Japan

H. Kitamura

Department of Nutritional Sciences for Well-being,

Kansai University of Welfare Sciences, Kashiwara, Japan

T. Sato

Department of Pediatrics, Kochi Medical School, Kochi, Japan

A. Maeda

Department of Pediatrics, Kochi Prefectural Hatakenmin

Hospital, Kochi, Japan double-stranded DNA and complement, but his proteinuria worsened and he developed acute nephritic-nephrotic syndrome. Monthly intravenous cyclophosphamide (IVCY) therapy dramatically reduced his proteinuria and led to complete remission (urinary protein/creatinine ratio $<0.1$ $\mathrm{mg} / \mathrm{mg}$ ), with gradual improvement in levels of serological markers. EBV antibody titers and EBV polymerase chain reaction (PCR) of peripheral blood lymphocytes suggested that the onset of iSLE might have been associated with EBV infection. At his 2-year follow-up visit, he was healthy and remained in complete remission. We conclude that IVCY treatment might be well tolerated and effective in cases of iSLE. EBV infection might play an important role in the pathogenesis of iSLE.

Keywords Infant - Intravenous cyclophosphamide · Lupus nephritis - Systemic lupus erythematosus · Epstein-Barr virus

\section{Introduction}

Systemic lupus erythematosus (SLE) has onset in childhood in 10-15\% of cases [1, 2]. Infantile SLE (iSLE; age at onset $<2$ years) is extremely rare and has been reported to be a much more severe disease with higher mortality and morbidity rates than SLE with onset at older age $[1,2]$. There is a close association between Epstein-Barr virus (EBV) infection and SLE induction in both adults and children [3]. We describe herein a 14-month-old Japanese boy with iSLE complicated by severe lupus nephritis (LN) classified as International Society of Nephrology/Renal Pathology Society (ISN/RPS) class IV, and EBV infection. He was successfully treated with intravenous cyclophosphamide (IVCY), which led to complete clinical remission without severe complications. 


\section{Case report}

A 14-month-old Japanese boy with 1-month history of recurrent fevers and recent onset of gross hematuria was admitted to our hospital. At age 10 months, he had been admitted to a local hospital because of pneumonia and had been found to have mild liver dysfunction. At that time, his serum anti-EBV viral capsid antigen (VCA)-immunoglobulin M (IgM), VCA-IgG, and EBV nuclear antigen (EBNA) titers were all less than 1:10. Tests for hepatitis virus antigens were all negative. His serum alanine aminotransferase (ALT) level remained elevated at 120-170 U/l, but the cause of this was not clear. His family reported excessive cutaneous swelling after mosquito bites. There was no family history of autoimmune disease. On admission, his blood pressure was $101 / 52 \mathrm{mmHg}$ and body temperature was $36.5^{\circ} \mathrm{C}$. He had a malar rash and a discoid rash on his extremities. His mother reported that these rashes worsened after exposure to sunlight.

The patient's laboratory findings are presented in Table 1. He was diagnosed with SLE according to the American Rheumatism Association criteria, based on his malar rash, discoid rash, photosensitivity, positive antinuclear antibody, positive anti-double stranded DNA (dsDNA) antibody, and renal dysfunction. Histological examination of a renal biopsy specimen showed diffuse LN classified as ISN/ RPS class IV-G (A) associated with cellular and fibrous crescents (25\%), wire loop lesions, and focal necrosis (Fig. 1). Immunofluorescence revealed "full-house" staining for $\mathrm{C} 3, \mathrm{C} 4, \mathrm{C} 1 \mathrm{q}, \mathrm{IgG}, \mathrm{IgA}$, and IgM in the mesangial and endocapillary regions. Liver biopsy showed inflammatory cell infiltration of the portal areas, composed primarily of lymphocytes, suggesting lupus hepatitis. In situ hybridization did not show EBV-encoded RNA in the liver or renal tissues.

Before starting treatment, the patient was tested for viral infections, because several viruses are known to be environmental triggers of SLE [4]. Serology for hepatitis B and $\mathrm{C}$ virus was negative. Cytomegalovirus (CMV) IgM and IgG titers were equivocal and positive, respectively. Serum antibody testing for EBV was positive with anti-VCA IgG titer of 1:640, anti-EBNA IgG titer of 1:20, anti-VCA IgM titer of less than 1:10, and anti-early antigen IgG titer of less than 1:10. Because of his hypersensitivity to mosquito bites, which is a characteristic symptom of chronic active EBV infection, PCR analysis was performed on peripheral mononuclear cells. The EBV load in peripheral mononuclear cells was 1,300 copies/ $\mu$ g DNA, with 229 copies/ $\mu \mathrm{g}$ DNA in CD4-positive cells, 1,691 copies/ $\mu \mathrm{g}$ DNA in CD8positive cells, 35,140 copies/ $\mu \mathrm{g}$ DNA in CD19-positive cells, and 7,204 copies/ $\mu \mathrm{g}$ DNA in CD56-positive cells. These findings indicate that the primary site of EBV
Table 1 Laboratory findings on admission

\begin{tabular}{|c|c|c|c|}
\hline \multicolumn{2}{|c|}{ Blood cell count } & \multicolumn{2}{|l|}{ Serological test } \\
\hline WBC & $11,600 / \mu 1$ & $\operatorname{IgG}$ & $\begin{array}{l}981 \mathrm{mg} / \mathrm{dl} \\
\quad(N 460-1,220)\end{array}$ \\
\hline $\mathrm{RBC}$ & $416 \times 10^{4} / \mu 1$ & $\operatorname{Ig} \mathrm{A}$ & $\begin{array}{l}136 \mathrm{mg} / \mathrm{dl} \\
\quad(N \mathrm{16}-128)\end{array}$ \\
\hline $\mathrm{Hb}$ & $9.9 \mathrm{~g} / \mathrm{dl}$ & $\operatorname{IgM}$ & $\begin{array}{l}144 \mathrm{mg} / \mathrm{dl} \\
(N 57-260)\end{array}$ \\
\hline $\mathrm{Ht}$ & $30.5 \%$ & $\operatorname{IgE}$ & $\begin{array}{c}1,057 \mathrm{IU} / \mathrm{ml} \\
(N<30)\end{array}$ \\
\hline Plt & $13.3 \times 10^{4} / \mu 1$ & $\mathrm{C} 3$ & $\begin{array}{l}23 \mathrm{mg} / \mathrm{dl} \\
\quad(N \text { 58-107) }\end{array}$ \\
\hline \multicolumn{2}{|c|}{ Coagulation } & $\mathrm{C} 4$ & $4 \mathrm{mg} / \mathrm{dl}(N$ 14-46) \\
\hline APTT & $28.9 \mathrm{~s}$ & $\mathrm{CH} 50$ & $<10 \mathrm{U} / \mathrm{ml}(\mathrm{N} 24-46)$ \\
\hline PT & $9.8 \mathrm{~s}$ & ANA & $\times 640(N<\times 40)$ \\
\hline Fib & $419 \mathrm{mg} / \mathrm{dl}$ & Anti-dsDNA Ab & $540 \mathrm{IU} / \mathrm{ml}(N<12)$ \\
\hline D-dimer & $5.1 \mu \mathrm{g} / \mathrm{ml}$ & Anti-RNP Ab & Negative \\
\hline FDP & $8 \mu \mathrm{g} / \mathrm{ml}$ & Anti-Sm Ab & Negative \\
\hline \multicolumn{2}{|c|}{ Blood chemistry } & Anti-SS-A Ab & Negative \\
\hline $\mathrm{TP}$ & $6.4 \mathrm{~g} / \mathrm{dl}$ & Anti-SS-B Ab & Negative \\
\hline Alb & $3.5 \mathrm{~g} / \mathrm{dl}$ & PR3-ANCA & Negative \\
\hline GOT & $163 \mathrm{U} / 1$ & MPO-ANCA & Negative \\
\hline GPT & $103 \mathrm{U} / \mathrm{l}$ & LE test & Positive \\
\hline $\mathrm{LDH}$ & $390 \mathrm{U} / 1$ & $\begin{array}{l}\text { Lupus } \\
\text { anticoagulant }\end{array}$ & Negative \\
\hline ALP & $629 \mathrm{U} / 1$ & ESR & $75 \mathrm{~mm} / \mathrm{h}$ \\
\hline T-Cho & $176 \mathrm{mg} / \mathrm{dl}$ & ASLO & $<2 \mathrm{IU} / \mathrm{ml}$ \\
\hline BUN & $0.2 \mathrm{mg} / \mathrm{dl}$ & Urinalysis & \\
\hline T-Bil & $31 \mathrm{mg} / \mathrm{dl}$ & $\mathrm{pH}$ & 6.0 \\
\hline Cre & $0.39 \mathrm{mg} / \mathrm{dl}$ & Protein & $(3+)$ \\
\hline $\mathrm{Na}$ & $138 \mathrm{mEq} / \mathrm{l}$ & UPCR & $13.2 \mathrm{mg} / \mathrm{mg}$ \\
\hline $\mathrm{K}$ & $5.1 \mathrm{mEq} / \mathrm{l}$ & Glucose & $(-)$ \\
\hline $\mathrm{Cl}$ & $109 \mathrm{mEq} / \mathrm{l}$ & Occult blood & $(3+)$ \\
\hline \multirow[t]{5}{*}{$\beta 2 \mathrm{MG}$} & $\begin{array}{r}6.29 \mu \mathrm{g} / \mathrm{ml} \\
(N 0.5-3)\end{array}$ & $\mathrm{RBC}$ & 100/HPF \\
\hline & & WBC & 10-19/HPF \\
\hline & & Hyaline casts & 3-9/LPF \\
\hline & & Epithelial casts & $0-1 / \mathrm{LPF}$ \\
\hline & & $\mathrm{eGFR}^{\mathrm{a}}$ & $84 \mathrm{ml} / \mathrm{min} / 1.73 \mathrm{~m}^{2}$ \\
\hline
\end{tabular}

$N$ normal range

a eGFR, estimated glomerular filtration rate calculated according to the equation 0.413 (height/serum creatinine) [16]

infection was not NK/T cells but B cells, suggesting EBV infection without chronic active EBV infection [5].

After admission, he developed spiking fevers, and his general condition worsened. We administered weekly pulse methylprednisolone (mPSL) treatment $(30 \mathrm{mg} / \mathrm{kg} / \mathrm{day}$ for 3 days) for 3 weeks, followed by oral prednisone $(2 \mathrm{mg} / \mathrm{kg} /$ day). We also administered itraconazole ( $2 \mathrm{mg} / \mathrm{kg} /$ day) to prevent fungal infection. After the initiation of mPSL 


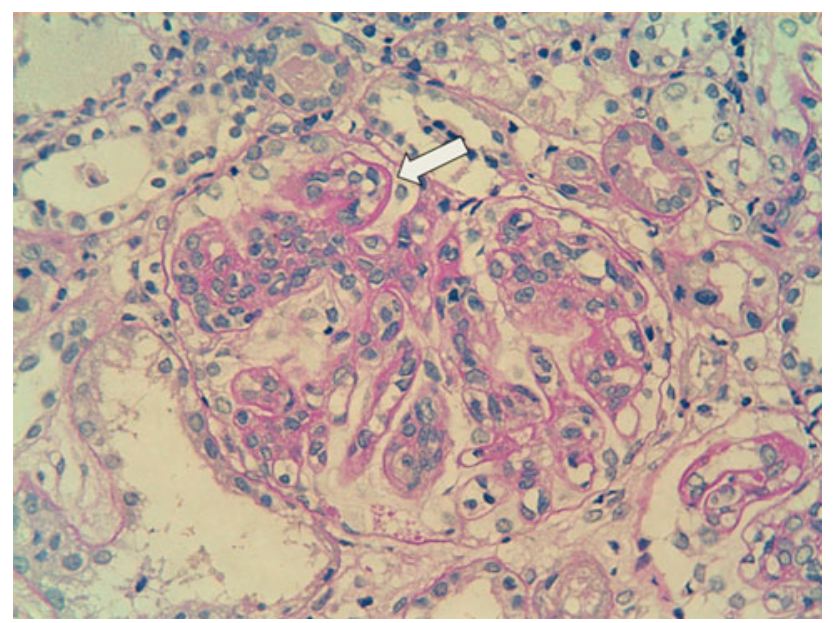

Fig. 1 Renal biopsy specimen demonstrating a wire loop lesion (white arrow) characteristic of lupus nephritis (periodic acid Schiff $\times 400)$

treatment, his fever immediately resolved and his serum ALT level returned to normal. After 3 weeks of mPSL treatment, his $\mathrm{C} 3, \mathrm{C} 4$, and $\mathrm{CH} 50$ levels increased to $52 \mathrm{mg} / \mathrm{dl}, 7 \mathrm{mg} / \mathrm{dl}$, and $30 \mathrm{IU} / \mathrm{ml}$, respectively, and his antidsDNA level decreased to $37 \mathrm{IU} / \mathrm{ml}$. However, macroscopic hematuria and massive proteinuria (urinary protein/ creatinine ratio $10-25 \mathrm{mg} / \mathrm{mg}$ ) persisted, resulting in hypoproteinemia (serum total protein concentration $4.6 \mathrm{~g} /$ $\mathrm{dl}$, albumin concentration $1.8 \mathrm{~g} / \mathrm{dl}$ ), ascites, edema, and eventually nephritic-nephrotic syndrome. Serum creatinine level peaked at $0.69 \mathrm{mg} / \mathrm{dl}$, and eGFR decreased to $48 \mathrm{ml} /$ $\min / 1.73 \mathrm{~m}^{2}$. We therefore initiated monthly IVCY treatment $\left(500-750 \mathrm{mg} / \mathrm{m}^{2}\right.$ ) after obtaining informed consent from his parents. As the fourth IVCY treatment was complicated by prolonged leukopenia, we extended subsequent IVCY intervals to bimonthly. After six IVCY treatments, his proteinuria had resolved completely (urinary protein/ creatinine ratio $<0.1 \mathrm{mg} / \mathrm{mg}$ ), his gross hematuria had resolved, and his renal function had normalized. He was started on mizoribine treatment, and his prednisolone dose was slowly tapered. At his 2-year follow-up visit, his clinical presentation, serological markers including dsDNA and complement, and urinary analysis were normal.

\section{Discussion}

Infantile SLE is very rare; to the best of our knowledge only 13 cases have been reported in the literature [1]. The overall prognosis of iSLE is very poor. Of the 13 reported patients, 5 died and 5 developed end-stage renal failure and central nervous system complications. The prognosis of iSLE with diffuse LN (ISN/RPS grades IV and V) is particularly poor $[1,6,7]$. Our patient had ISN/RPS grade IV LN associated with acute nephritic-nephrotic syndrome, suggesting that his prognosis may have been poor without aggressive immunosuppressive treatment. IVCY is currently the standard treatment for both children and adults with severe LN [8-10]. However, the effectiveness of IVCY treatment for iSLE remains unclear. There is only one previous report of successful IVCY treatment, in a 10-month-old patient with iSLE who had World Health Organization class IV LN [7]. That patient received monthly IVCY treatments for 6 months followed by 3-monthly IVCY treatments for another 6 months, and achieved complete clinical and serological remission for 2 years. The outcome in our patient also suggests that IVCY might be an effective treatment for maintaining long-term clinical and serological remission of iSLE.

Infection is a risk factor for mortality in SLE patients [11]. As the possibility of fungal infection is of particular concern in SLE patients treated by immunosuppressive agents, we administered prophylactic itraconazole to our patient. We monitored C-reactive protein and 1,3- $\beta$-D glucan levels, but did not detect any significant infections. We think that prophylactic use of itraconazole might be safe and effective in iSLE patients undergoing aggressive immunosuppressive treatment.

It is generally accepted that the clinical course of SLE is influenced by both genetic and environmental factors, including viral infections [12]. There are many indications that EBV infection may lead to the development of SLE. Some patients have developed SLE immediately after EBV-induced infectious mononucleosis, and elevated serum anti-EBV antibody levels or EBV loads in lymphocytes are often observed in patients with SLE [13, 14]. It has been postulated that anti-EBNA-1 antibody generated in EBV infection cross-reacts with lupus-specific autoantigens ( $\mathrm{Sm}$ or Ro) and subsequently contributes to harmful autoimmune reactions, leading to the development of SLE [13, 15]. Considering the relatively high levels of EBV-DNA load in B cells (CD19+) and the seroconversion of EBV-VCA and EBNA IgG, we speculate that primary EBV infection of $B$ cells might have been associated with the onset of iSLE in this case.

In conclusion, we report a patient with iSLE with severe LN who was successfully treated with IVCY. This case illustrates the close relationship between EBV infection and the development of iSLE in pediatric patients.

Conflict of interest All the authors have declared no competing interests.

\section{References}

1. Zulian F, Plunchinotta FR, Martini G, Da Dalt L, Zachello G. Severe clinical course of systemic lupus erythematosus in the first year of life. Lupus. 2008;17:780-6. 
2. Pluchinotta FR, Schiavo B, Vittadello F, Perilongo G, Zulian F. Distinctive clinical features of pediatric systemic lupus erythematosus in three different age classes. Lupus. 2007;16:550-5.

3. Toussirot E, Roudier J. Epstein-Barr virus in autoimmune diseases. Best Pract Res Clin Rheumatol. 2008;22:883-96.

4. Doria A, Sarzi-Puttini P, Shoenfeld Y. Infections, rheumatism and autoimmunity: the conflicting relationship between humans and their environment. Autoimmun Rev. 2008;8:1-4.

5. Okano M, Kimura H, Yachhie A, Wakiguchi $H$, Maeda A, Imai S, Ohga S, Kanegane H, Tsuchiya S, Morio T, Mori M, Yokota S, Imashuku S. Proposed guidelines for diagnosing chronic active Epstein-Barr virus infection. Am J Hematol. 2005;80:64-9.

6. Kreindler J, Ellis D, Vats A, Kurland G, Ranganathan S, Molitz ML. Infantile systemic lupus erythematosus presenting with pulmonary hemorrhage. Pediatr Nephrol. 2005;20:522-5.

7. Saberi MS, Jones BA. Remission of infantile lupus erythematosus with intravenous cyclophosphamide. Pediatr Nephrol. 1998;12: 136-8.

8. Yildirim-Toruner C, Diamond B. Current and novel therapeutics in the treatment of systemic lupus erythematosus. J Allergy Clin Immunol. 2011;127:303-12.

9. Molino C, Fabbian F, Longhini C. Clinical approach to lupus nephritis: recent advances. Eur J Intern Med. 2009;20:447-53.
10. Adams A, MacDermott EJ, Lehman TJ. Pharmacotherapy of lupus nephritis in children: a recommended treatment approach. Drugs. 2006;66:1191-207.

11. Laoprasopwattana K, Dissaneewate P, Vachvanichsanong P. Fatal infection in children with lupus nephritis treated with intravenous cyclophosphamide. Pediatr Nephrol. 2009;24:1337-43.

12. Goddard GZ, Berkun Y, Barzilai O, Boaz M, Blank M, Ram M, Sherer Y, Anaya JM, Shoenfeld Y. Exposure to Epstein-Barr virus infection is associated with mild systemic lupus erythematosus disease. Ann N Y Acad Sci. 2009;1173:658-63.

13. Harley JB, James JA. Epstein-Barr virus infection induces lupus autoimmunity. Bull NYU Hosp JT Dis. 2006;64:45-9.

14. Poole BD, Templeton AK, Guthridge JM, Brown EJ, Harley JB, James JA. Aberrant Epstein-Barr viral infection in systemic lupus erythematosus. Autoimmun Rev. 2009;8:337-42.

15. Kasapcopur O, Ergul Y, Kutlug S, Candan C, Camcioglu Y, Arisoy N. Systemic lupus erythematosus due to Epstein-Barr virus or Epstein-Barr virus infection provocating acute exacerbation of systemic lupus erythematosus? Rheumatol Int. 2006;26: $765-7$.

16. Schwartz GJ, Muñoz A, Schneider MF, Mak RH, Kaskel F, Warady BA, Furth SL. New equations to estimate GFR in children with CKD. J Am Soc Nephrol. 2009;20:629-37. 